\title{
Changes in bacterial and archaeal assemblages in an equatorial river induced by the water eutrophication of Petit Saut dam reservoir (French Guiana)
}

\author{
Jean-François Dumestre ${ }^{1}$, Emilio O. Casamayor ${ }^{2, *}$, Ramon Massana $^{2}$, \\ Carlos Pedrós-Alió ${ }^{2}$
}

${ }^{1}$ Centre d'Ecologie des Systèmes Aquatiques Continentaux, UMR CNRS/UPS C5576, Université Paul Sabatier, 31062 Toulouse cedex, France

${ }^{2}$ Departament de Biologia Marina i Oceanografia, Institut de Ciències del Mar, CMIMA-CSIC, 08003 Barcelona, Spain

\begin{abstract}
The microbial assemblages of Petit Saut reservoir and Sinnamary river (French Guiana, South America) were analyzed by biochemical analyses (pigments and specific fatty acids), and by polymerase chain reaction (PCR) denaturing gradient gel electrophoresis (DGGE) and sequence analysis of $16 \mathrm{~S}$ rRNA gene fragments. Samples from a vertical profile in the reservoir and from a longitudinal profile downstream of the dam were analyzed and compared to a reference sample taken in the river, upstream of the reservoir. The distribution of bacterial populations could be explained by the physico-chemical conditions of the water and the hydrodynamics induced by the hydroelectric plant. Two bacterial 'bio-filters' were detected by biochemical analyses: methanotrophs at the oxycline level and phototrophic green sulfur bacteria below the oxycline. A statistical analysis of the DGGE fingerprints obtained for each sample showed that the different stations could be related in a dendrogram in good agreement with their geographic location. We detected 53 bands in the bacterial DGGE fingerprints and 3 bands in the archaeal DGGE. The phylogenetic affiliation of the predominant DGGE bands was inferred by a comparative 16S rDNA partial sequence analysis (450 to 500 base pairs). Sequences obtained from the reservoir and the river were related to Proteobacteria $(\alpha, \beta$, and $\gamma)$, Cyanobacteria, green sulfur bacteria, Cytophaga, Methanomicrobiaceae and Thermoplasmales. Thus, methanotrophs and green sulfur bacteria were detected, and bacteria involved in the iron biogeochemical cycle were also shown to be dominant. The 16S rDNA-based analysis indicated that new bacterial and archaeal lineages, not detected upstream of the dam, were present in the reservoir and that the microbial diversity of these assemblages was greater than previously described by biochemical analyses. Our data provide evidence that the former bacterial assemblage was completely modified by the impounding of the reservoir, in agreement with the different biogeochemical cycles established. Minor groups of bacteria became dominant in the reservoir while others disappeared, in adaptation to the new conditions induced by flooding of rain forest.
\end{abstract}

KEY WORDS: Archaea $\cdot$ Bacteria $\cdot$ Biogeochemical cycles $\cdot$ DGGE $\cdot$ Equatorial reservoir $\cdot$ Microbial assemblages $\cdot 16 \mathrm{~S}$ rDNA

\section{INTRODUCTION}

Application of $16 \mathrm{~S}$ rRNA-based molecular techniques has allowed determination of the identity of

${ }^{*}$ Corresponding author. Present address: Observatoire Océanologique de Banyuls-CNRS, BP 44, 66651 Banyulssur-Mer, France. E-mail: emilio@obs-banyuls.fr microbial cells in their natural environment (see recent reviews in Amann et al. 1995, Muyzer 1998). On the other hand, activities of prokaryotic assemblages are often analyzed in microbial ecology studies (e.g. Dumestre et al. 1999a). The challenge is now to combine both approaches to determine the in situ activity of specific microbes (e.g. Ouverney \& Fuhrman 1999). Relating in situ activity to particular prokaryotes 
remains, however, one of the most difficult problems in microbial ecology. Here, we use a well-studied eutrophic reservoir as an example of a location where both functional and genetic information can be compared for the same planktonic system.

Petit Saut reservoir is an equatorial freshwater system built by Electricité de France Company in the course of the Sinnamary River (French Guiana). More than $360 \mathrm{~km}^{2}$ of equatorial rain forest were flooded, starting in January 1994. The anaerobic degradation of submerged organic matter (aerial biomass: $100 \times 10^{3}$ to $200 \times 10^{3} \mathrm{~kg} \mathrm{C} \mathrm{ha}^{-1}$, soil biomass: $100 \times 10^{3} \mathrm{~kg} \mathrm{C} \mathrm{ha}^{-1}$ ) (CDIC 1986) rapidly induced production of methane and sulfide through archaeal and bacterial activities. This set of conditions provided a very good opportunity for combining detailed microbiological and physicochemical studies in a system formed de novo. These studies showed that, in just $1 \mathrm{yr}$, the reservoir shifted from being a body of water containing microorganisms with a predominantly anaerobic organotrophic metabolism to one containing lithotrophic bacteria, which have been present since then (Dumestre et al. 1999b). At present, the top of the water column is well oxygenated and the bottom is anoxic and rich in methane with presence of sulfide and reduced iron compounds present. Several microbial populations distributed vertically along the physico-chemical gradient are generated in the water column (Dumestre et al. 1999b). Downstream of the dam, released water is reoxygenated by an artificial waterfall installed a few meters beyond the hydroelectric plant. This yields a mixed water quality, composed of reduced elements, oxygen, and both anaerobic and aerobic microorganisms. Along the $40 \mathrm{~km}$ to the Atlantic Ocean, the water recovers its former quality and microbial activities adapt progressively (Dumestre et al. 1999b). Using traditional methods, 2 main bacterial guilds situated above and below the oxycline, i.e. methanotrophs and green sulfur bacteria, were detected and studied (Dumestre et al. 1999a). Both groups were easily studied because of the presence of marker fatty acids and pigments and because they showed a characteristic stratified arrangement in the lake, forming active biological filters limiting the emission of methane and sulfide, respectively, into the atmosphere. However, other microbial groups (probably important too, like chemolithoautotrophic sulfur bacteria) were not targeted in these studies because of they lacked appropriate marker pigments and fatty acids or could not be cultivated successfully.

Over the past decade, several molecular techniques have been developed in order to study natural microbial communities in a culture-independent way using RNA and RNA genes as biomarkers (Muyzer 1998). Denaturing gradient gel electrophoresis (DGGE) of polymerase chain reaction (PCR)-amplified 16S rRNA genes is a fingerprinting technique widely used to study complex microbial assemblages (Muyzer et al. 1998). Despite biases and the limitations of PCR amplification and DGGE separation, this method gives valuable information on the dynamics and composition of the main components of natural assemblages (e.g. Casamayor et al. 2000, Schauer et al. 2000). In addition, DGGE is very useful for providing an overview of the microbial diversity after sequencing of excised bands from the gel.

The present work focused on the study of the bacterial and archaeal assemblages in a vertical profile of the Petit Saut reservoir and in different places upstream and downstream of the Sinnamary River by DGGE sequencing, microscopy, and biochemical analysis. Several physico-chemical parameters were determined in these locations. Biochemical analysis focused on specific bacteriochlorophylls from green sulfur bacteria and on fatty acids from sulfate-reducing bacteria and methanotrophs. The shift in the microbial assemblage caused by the presence of the reservoir was addressed by fingerprinting analysis. DGGE and sequencing of $16 \mathrm{~S}$ rDNA fragments retrieved those previously studied bacterial populations, and new populations belonging to other physiological guilds were identified, revealing which were the main biogeochemical players in the system.

\section{MATERIAL AND METHODS}

Description of the system and sampling. Petit Saut reservoir is located in the French Guiana Amazonian rain forest $\left(53^{\circ} 15^{\prime} \mathrm{E}, 5^{\circ} 05^{\prime} \mathrm{N}\right)$. The dam interrupts the course of the Sinnamary River, but flooding also involves many tributaries because this river has very steep banks and uneven shorelines. Maximal length of the reservoir is about $40 \mathrm{~km}$, maximal depth is $35 \mathrm{~m}$, and minimal outflow is maintained at $100 \mathrm{~m}^{3} \mathrm{~s}^{-1}$. The system is meromictic with a permanent thermocline because of poor wind mixing and the narrow range of seasonal variation in air temperature. Thus, physico-chemical parameters of the water column are quite stable over the year, in spite of the alternating rainy and dry seasons. To allow comparison between different years, all the results presented in this work have been obtained during periods of similar outflow conditions, about $250 \mathrm{~m}^{3} \mathrm{~s}^{-1}$. The first 5 to $7 \mathrm{~m}$ of the water column were well oxygenated, and the bottom waters were anoxic and rich in methane and sulfide. Nine previously studied sites (Dumestre et al. 1999b) were sampled along the entire ecosystem (80 km long) from the incoming river (Takari Tanté site) to the sea (Fig. 1). At the Barge Petit Saut (BPS) floating station (300 m away 


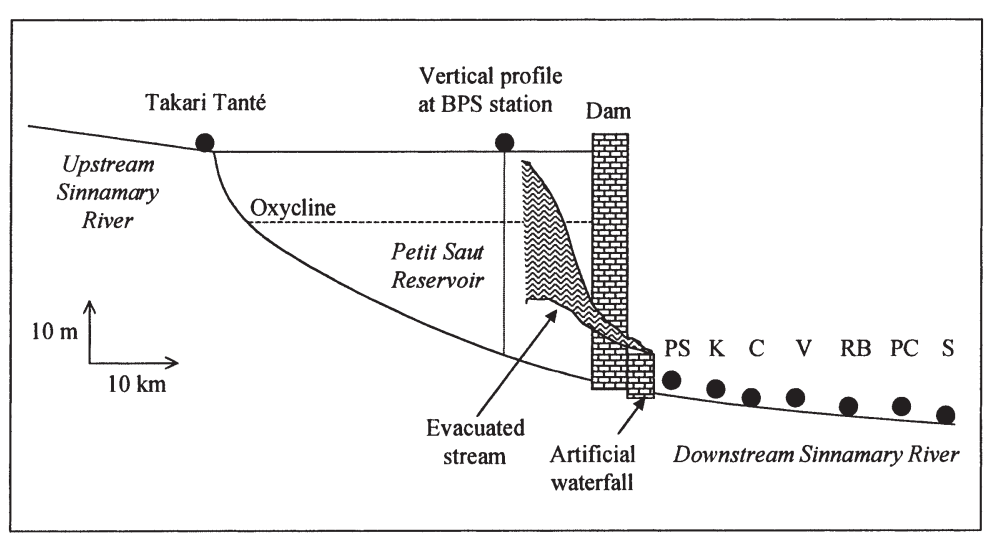

Fig. 1. Longitudinal transect across the system of Petit Saut, from the former Sinnamary River to the harbor (about $80 \mathrm{~km}$ long) showing location of the stations. BPS: Barge Petit Saut; C: Chapeau; K: Kérenroch; PC: Pointe Combi; PS: Petit Saut; RB: Roche Bravo; S: Sinnamary; V: Vénus according to Henry's law (Galy-Lacaux et al. 1997).

Total numbers of prokaryotes (bacteria and archaea) were determined by epifluorescence microscopy after staining with 4'-6-diamidino-2-phenylindole (DAPI) according to Porter \& Feig (1980). Samples were preserved with a $4 \%$ (vol/vol) final concentration of formaldehyde and conserved in polystyrene flasks at $4^{\circ} \mathrm{C}$. Cells were counted with a Leitz-Dialux 22 epifluorescence microscope. Thirty fields per slide were enumerated with an average of 100 to 150 bacteria field $^{-1}$. For bacteriochlorophyll analysis $500 \mathrm{ml}$ of water was filtered on $0.2 \mu \mathrm{m}$ pore membrane filters (Nuclepore). The samples were preserved at $-18^{\circ} \mathrm{C}$ until analysis. The procedure of extraction with acetone and the determi-

from the dam wall), 8 additional water samples were collected at different depths. Downstream of the dam, 7 other sites were investigated: Petit Saut (PS), Kérenroch (K), Chapeau (C), Vénus (V), Roche Bravo (RB), Pointe Combi (PC), and Sinnamary (S). These 7 sites were sampled at a $20 \mathrm{~cm}$ depth in the middle of the river bed. Samples for fatty acids and pigments analysis were collected in December 1996. Samples for 16S rDNA-based analyses were collected during August 1999.

Sampling was carried out using a peristaltic pump and a syringe, the needle pushed through a septum placed before the pump head. This system avoids gas stripping. Dissolved oxygen, $\mathrm{pH}$, temperature, conductivity, and turbidity were measured by a YSI-Grant 3890 multivariable probe (Grant Instruments, Cambridge, UK) and a WTW OXY 196 oxymeter (Wissenschaftlich Technische Werkstatten, Weilheim, Germany). Total sulfides were quantified using a colorimetric method (Cline 1969) with a Spectronic 401 cell spectrophotometer (Milton Roy, Ivyland, PA, USA) at $670 \mathrm{~nm}$ on samples preserved with zinc acetate. Sulfates were determined by nephelometry, using barium chloride (Richard et al. 1997). Total iron was measured by atomic absorption spectrometry with an air-acetylene flame, at $248.3 \mathrm{~nm}$ (Richard et al. 1997). Dissolved methane in water was analyzed by gas chromatography (GC), after degassing $2 \mathrm{ml}$ of water in a $57 \mathrm{ml}$ glass flask, closed with a Teflon septum and emptied with a vacuum pump. Atmospheric pressure was restored in the headspace and $500 \mu$ l was withdrawn for analysis. A Hewlett Packard 5890 A GC fitted with a flame ionization detector and a Porapak $\mathrm{Q}$ semi-capillary column (injector: $200^{\circ} \mathrm{C}$, detector: $200^{\circ} \mathrm{C}$, carrier gas: $\mathrm{He}$ ) were used. Methane concentration in the gaseous phase was measured in the same way and the initial concentration in the water sample determined nation of bacteriochlorophyll pigments by HPLC was described in Le Bris et al. (1998).

Phospholipid fatty acid (PLFA) analysis. Water samples $(150$ to $500 \mathrm{ml}$ ) were filtered on $0.2 \mu \mathrm{m}$ pore polycarbonate membranes (Nuclepore). The samples were freeze-dried until treatment. Total lipids were extracted with a modified Bligh \& Dyer extraction procedure (White et al. 1979). The extracted lipids were fractionated into neutral lipids, glycolipids, and polar lipids by silica column chromatography and sequentially eluted with dichloromethane, acetone, and methanol. The methanol fraction (polar lipids) was dried in a nitrogen atmosphere and subjected to acid methanolysis. Nonadecanoic acid was added before methanolysis as an internal standard. The resulting fatty acid methyl esters were dissolved in $50 \mu$ dichloromethane and analyzed by GC. The double bond position in the monounsaturated fatty acids was determined using dimethyl disulfide derivatization. The double bond positions of the polyunsaturated fatty acids were determined after 4,4-dimethyloxazoline derivatization. Detailed GC-mass spectrometry (MS) procedures are reported elsewhere (Guézennec \& Fiala-Medioni 1996). PLFAs are identified in the form of 2 numbers separated by a colon (e.g. 16:1 18 ). The number before the colon indicates the carbon chain length and the number after the colon refers to the number of double bonds. The position of the double bond is defined by the letter $\omega$ followed by the number of carbons from the methyl end.

Nucleic acid extraction, PCR, and DGGE. Between 150 and $200 \mathrm{ml}$ water was pre-filtered through a $20 \mu \mathrm{m}$ pore net, to eliminate large zooplankton and algae, filtered on $0.2 \mu \mathrm{m}$ pore polycarbonate membranes (Nuclepore) and freeze-dried until treatment. Then, filters were incubated with lysozyme, Proteinase $K$, and 
sodium dodecyl sulfate (SDS) in lysis buffer $(40 \mathrm{mM}$ EDTA, $50 \mathrm{mM}$ Tris pH 8.3, $0.75 \mathrm{M}$ sucrose). DNA was extracted with phenol-chloroform-isoamyl alcohol $(25: 24: 1, \mathrm{vol} / \mathrm{vol} / \mathrm{vol})$ and with chloroform:isoamyl alcohol $(24: 1, \mathrm{vol} / \mathrm{vol})$. The aqueous phase was concentrated by centrifugation on a microconcentrator (Centricon 100, Amicon; 100000 molecular weight cut-off). This system allowed several rinsing phases that help to eliminate PCR inhibitors. Fragments of the $16 \mathrm{~S}$ ribosomal DNA suitable for DGGE analysis were obtained by using 2 primer combinations for different phylogenetic lineages (Table 1); one combination was used for Bacteria (Muyzer et al. 1998), and the second combination was used for Archaea (Casamayor et al. 2000). The length of the PCR products were 585 and 624 base pairs (bp), respectively. Bacterial PCR was performed as described elsewhere (Schauer et al. 2000), carrying out 30 amplification cycles at $55^{\circ} \mathrm{C}$ annealing temperature in a denaturing gradient 40 to $80 \%$ (100\% denaturant agent is $7 \mathrm{M}$ urea and $40 \%$ deionized formamide). For the archaeal PCR, 30 amplification cycles were run at a $61^{\circ} \mathrm{C}$ annealing temperature in accordance with a previous report (Casamayor et al. 2000). Bovine serum albumin was added to the reaction mixture $(150 \mu \mathrm{g}$ $\mathrm{ml}^{-1}$ final concentration) to minimize the inhibitory effect of humic substances on PCR amplification (Kreader 1996, Harry et al. 1999). DGGE was carried out with the DGGE-2000 system (CBS Scientific Company, Del Mar, CA, USA) as described in Muyzer et al. (1998) and Schauer et al. (2000). Bacterial DGGE was run at $100 \mathrm{~V}$ and $60^{\circ} \mathrm{C}$ during $16 \mathrm{~h}$, and archaeal DGGE at $250 \mathrm{~V}$ and $60^{\circ} \mathrm{C}$ during $5 \mathrm{~h}$. About $500 \mathrm{ng}$ of PCR product was deposited in each well. After electrophoresis, the gels were stained with GelStar (FMC Bioproducts, Rockland, ME, USA) and visualized with UV radiation (wavelength $314 \mathrm{~nm}$ ) with a Fluor-S MultiImager (BioRad). The high resolution digitized images were processed with the Diversity Database software (BioRad) in order to measure relative band intensities. The software performs a density profile through each lane, detects the bands, and calculates the relative contribution of each band to the total band signal in the lane after applying a rolling disc as back- ground. A band was defined as a stain signal whose intensity was more than $0.2 \%$ of the total intensity for each lane. Then, the bands occupying the same position in the different lanes of the gel were identified using software facilities and manual correction. A binary matrix (1/0) was made for all lanes, taking into account the presence or absence of individual bands. This matrix was used to build a similarity matrix based on the Jaccard coefficient (Sj). Finally, a dendrogram showing the relationships among samples was obtained with the unweighted pair group average linkage method (UPGMA). Prominent bands were excised from the gel. DNA was released from the polyacrilamide with a Mini Beadbeater-8 (Biospec Products, Bartlesville, OK, USA) and reamplified by PCR. The new products were purified by using a QIAquick PCR purification kit (Qiagen Inc.). A Thermo Sequenase ${ }^{\mathrm{TM}}$ II dye terminator cycle sequencing kit (Amersham) was used to sequence the 16S rDNA fragments with the appropriate forward PCR primer without the GC clamp.

Sequence analysis and construction of phylogenetic trees. A basic local alignment search (Altschul et al. 1990) on the internet (www.ncbi.nlm.nih.gov) was used to get a first indication of what sequences were retrieved. Sequences were aligned with the automated aligning tool of the ARB program package (Technical University of Munich, Munich, Germany; www.arbhome.de). A similarity matrix was constructed to obtain sequence similarity values. Then partial sequences were inserted into the optimized tree derived from the complete sequence data by using the maximum parsimony criterion and a special ARB parsimony tool that did not affect the initial tree topology. The resulting tree was pruned to save space, retaining only the closest relatives. A total of 17 partial sequences with lengths between 432 and 572 bp have been deposited in the EMBL nucleotide sequence database under the following accession numbers: AJ296581 to AJ296595 (PSBAC-1 to PSBAC-15) and AJ296596 to AJ296597 (PSARC-1 to PSARC-2). Each band designation includes (in addition to a number according to Figs $5 \& 6$ ) a code for Petit Saut and a code for the primer (BAC, Bacteria; ARC, Archaea).

Table 1. Sequences, target sites, and specificities of the primers used in this study

\begin{tabular}{|lcccc|}
\hline Primer & Target site & Sequence (5' to 3') & Specificity & Source \\
\hline 341F-GC & $341-357$ & CCT ACG GGA GGC AGC AG & Most Bacteria & Muyzer et al. (1998) \\
907R & $926-907$ & CCG TCA ATT CCT TTG AGT TT & Most known organisms & Muyzer et al. (1998) \\
ARC344F-GC ${ }^{\text {a }}$ & $344-363$ & ACG GGG YGC AGC AGG CGC GA & Most Archaea & Raskin et al. (1994) \\
ARC915R & $934-915$ & GTG CTC CCC CGC CAA TTC CT & Most Archaea & Stahl \& Amann (1991) \\
aCC is a 40-nucleotide GC-rich sequence attached to the 5' end of the primer. The GC sequence is 5'-CGC CCG CCG CGC \\
CCC GCG CCC GTC CCG CCG CCC CCG CCC G-3'
\end{tabular}




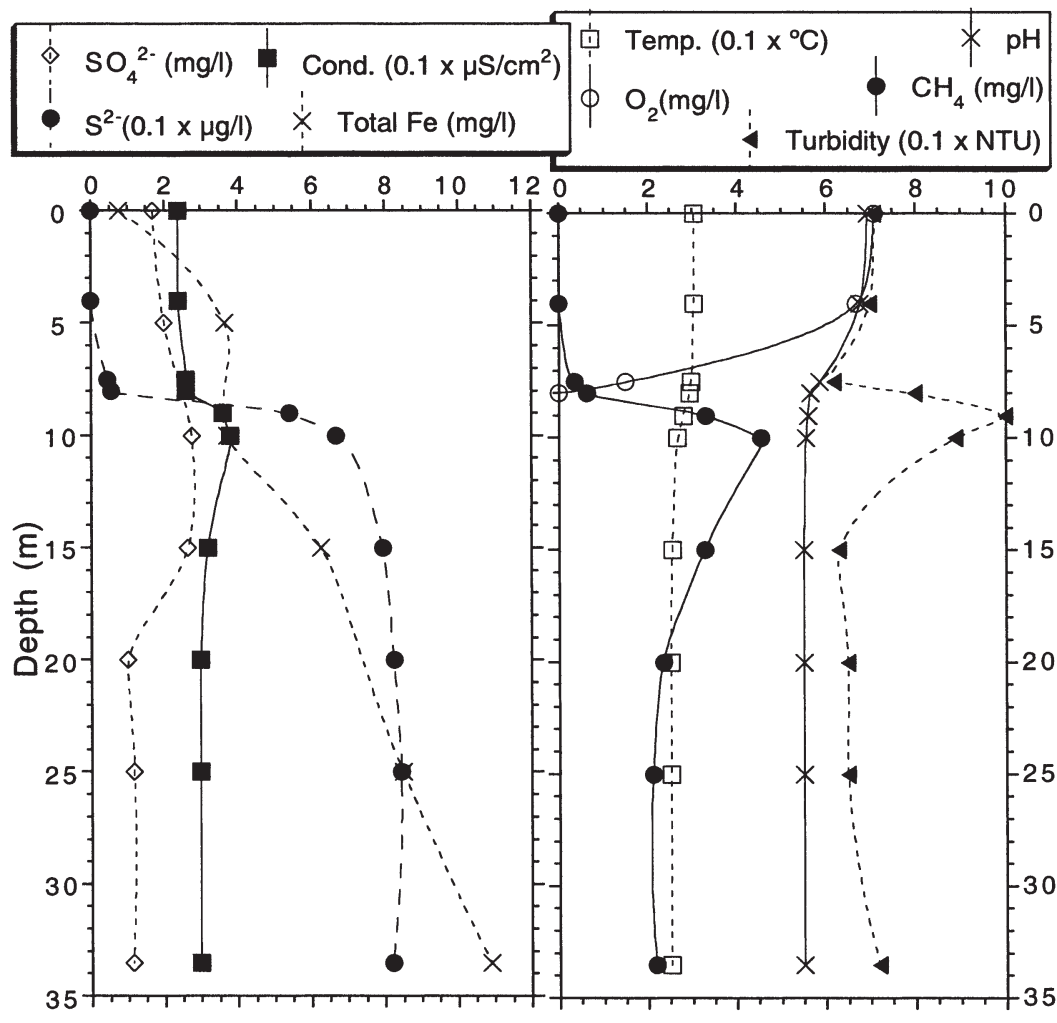

Fig. 2. Physico-chemical parameters measured at the BPS station in August 1999

dized during the first $10 \mathrm{~km}$, whereas methane oxidation occurred all along the transect. It has been shown that the strong depletion in methane concentration is due to biological methanotrophic activity (Gosse \& Grégorie 1997).

\section{Vertical distribution of bacterial populations}

The vertical profile of prokaryotic abundance showed a marked peak $2 \mathrm{~m}$ below the oxycline level, with a maximum of $15 \times 10^{6}$ cells ml ${ }^{-1}$ (Fig. 4). In the aerobic zone and at the bottom of the reservoir, prokaryotic abundance was about $5 \times 10^{6}$ cells $\mathrm{ml}^{-1}$. Such a vertical microbial accumulation was observed at different sites in the reservoir (data not shown). Photosynthetic sulfur bacterial populations accumulated about $2 \mathrm{~m}$ below the aerobic zone and were identified by HPLC. Bacteriochlorophyll $c$ (bchl $c$ ), bchl $d$, and the carotenoid chlorobactene were related to green sulfur bacteria. Bchl $c$ and $d$ were very abundant in a narrow layer below

\section{RESULTS}

\section{Physico-chemical parameters of the system}

Fig. 2 shows the vertical profile at BPS station for $\mathrm{pH}$, $\mathrm{O}_{2}, \mathrm{CH}_{4}$, temperature, turbidity, conductivity, sulfate, total iron, and sulfide, obtained in August 1999. Temperature ranged from $26^{\circ} \mathrm{C}$ at the bottom to $30^{\circ} \mathrm{C}$ at the surface, and small variations were also observed in conductivity. However, Petit Saut reservoir is stratified throughout year. The vertical profile of $\mathrm{pH}$ showed more acidic waters at greater depths ( $\mathrm{pH}$ 6), and marked gradients for $\mathrm{O}_{2}, \mathrm{CH}_{4}$, total sulfide, and total iron were observed between the aerobic and the anaerobic water masses. Methane concentrations were several times higher than those of sulfide in the dam and along the transect (Figs $2 \& 3$ ). Turbidity exhibited a peak just below the oxic-anoxic interface.

Downstream of the dam, the water evacuated is a mixture of upper and bottom water masses. Fig. 3 shows the changes in some physico-chemical parameters on the way from the dam to the harbor $(40 \mathrm{~km})$. Temperature and conductivity had similar values along this longitudinal profile, and $\mathrm{pH}$ equilibrated after $15 \mathrm{~km}$. Turbidity increased greatly after the Vénus station, where the most important tributary brought in a lot of suspended material. Sulfides oxi- the oxycline (Fig. 4). Pigments belonging to purple photosynthetic bacteria (bchl $a$ and carotenoids spirilloxanthin, rhodopine, and rhodopinal) were also detected in the reservoir (Le Bris et al. 1998).

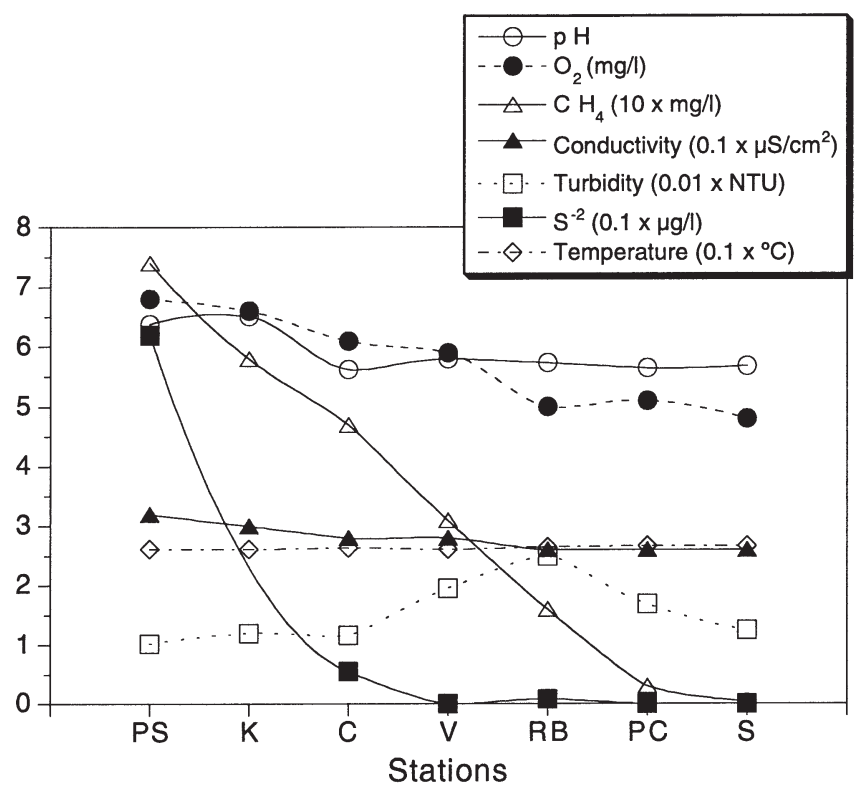

Fig. 3. Physico-chemical parameters measured in August 1999 in the Sinnamary River downstream of the dam 


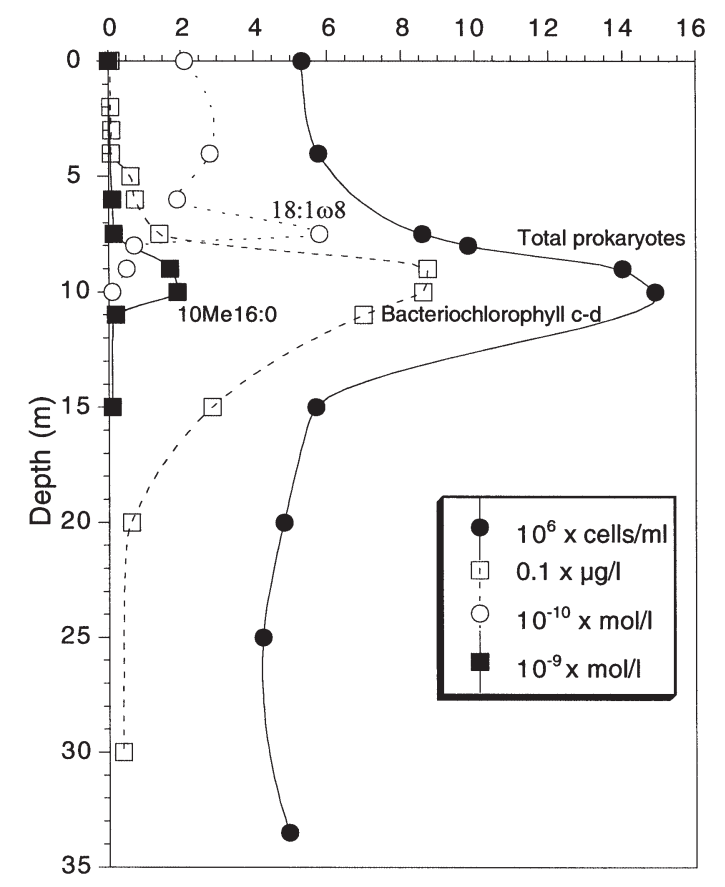

Fig. 4. Total bacterial counts, green sulfur bacteria-like bacteriochlorophylls, and specific PLFA, measured at the BPS station in December 1996
Other bacterial guilds were identified by PLFA analysis. Table 2 shows PLFA obtained from different depths in the reservoir. Only 2 fatty acids gave relevant information, i.e., the 10Me16:0 specific from the sulfate-reducing bacterium Desulfobacter (Taylor \& Parkes 1983) and the 18:168 specific from type II methanotrophs (Guckert et al. 1991). Vertical profiles in BPS station for these 2 specific PLFA are presented in Fig. 4. Sulfate reducers accumulated at the same depth as the green sulfur bacteria did and were not detected in the aerobic zone. Type II methanotrophs accumulated a few meters above sulfate reducers and were detected in the aerobic zone but not in deeper layers.

\section{DGGE fingerprinting}

DGGE analyses were performed in samples obtained at different depths in the reservoir and in several stations upstream and downstream of the reservoir (Figs 5 \& 6). Primer sets for Bacteria (Fig. 5), and for Archaea (Fig. 6) were used. The microbial assemblage produced a reproducible DGGE fingerprint in different analyses carried out in parallel. A low amount of bacterial PCR

Table 2. Phospholipid fatty acid (PLFA) profiles (in \% composition) and total PLFA concentration determined in December 1996 in different water samples at the BPS site. The oxycline was located at $7 \mathrm{~m}$

\begin{tabular}{|c|c|c|c|c|c|c|c|c|c|c|}
\hline \multirow{2}{*}{$\begin{array}{l}\text { Fatty } \\
\text { acid }\end{array}$} & \multirow[b]{2}{*}{$0 \mathrm{~m}$} & \multirow[b]{2}{*}{$4 \mathrm{~m}$} & \multirow[b]{2}{*}{$6 \mathrm{~m}$} & \multicolumn{3}{|c|}{ Composition (\%) at depth: } & \multirow[b]{2}{*}{$9 \mathrm{~m}$} & \multirow[b]{2}{*}{$10 \mathrm{~m}$} & \multirow[b]{2}{*}{$15 \mathrm{~m}$} & \multirow[b]{2}{*}{$32 \mathrm{~m}$} \\
\hline & & & & $6.5 \mathrm{~m}$ & $7 \mathrm{~m}$ & $8 \mathrm{~m}$ & & & & \\
\hline $\mathrm{i} 14: 0$ & 0.24 & 0.12 & 0.14 & 0.27 & 0.73 & 0.82 & 0.57 & 0.92 & 0.7 & 0.15 \\
\hline 14:0 & 6.69 & 2.47 & 5.59 & 5.66 & 8.85 & 8.08 & 5.03 & 7.97 & 5.15 & 2.39 \\
\hline i15:0 & 1.36 & 0.35 & 1.04 & 1.02 & 2.26 & 1.5 & 0.81 & 2.19 & 1.6 & 0.31 \\
\hline a15:0 & 0.67 & 0.2 & 0.92 & 0.6 & 1.84 & 2.16 & 1.41 & 2.75 & 1.89 & 0.35 \\
\hline $15: 0$ & 1 & 0.49 & 1.36 & 1.56 & 2.05 & 2.92 & 1.68 & 1.92 & 1.07 & 0.32 \\
\hline i16:0 & 0.31 & 0.12 & 0.36 & 0.24 & 0.94 & 1.03 & 0.56 & 1.28 & 1.02 & 0.2 \\
\hline $16: 1 \omega 9$ & 0.78 & 0.32 & 0.77 & 0.62 & 0.25 & 2.84 & 2.06 & 0.03 & 0.94 & 0.17 \\
\hline $16: 1 \omega 7$ & 5.76 & 0.76 & 3.07 & 3.08 & 10.48 & 5.74 & 1.71 & 2.88 & 0.96 & 0.13 \\
\hline $16: 0$ & 41.36 & 18.45 & 33.8 & 32.37 & 30.73 & 27.48 & 19.55 & 25.47 & 22.62 & 15.4 \\
\hline 10Me16:0 & $\mathbf{0}$ & $\mathbf{0}$ & 0.25 & 0.24 & $\mathbf{0}$ & 1.36 & 0.63 & 0.47 & 0.22 & 0.02 \\
\hline i17:0 & 0.21 & 0 & 0.19 & 0.23 & 0.62 & 0.36 & 0.22 & 0.44 & 0.42 & 0.09 \\
\hline a17:0 & 0.91 & 0.34 & 1.07 & 0.99 & 1.39 & 0.95 & 0.6 & 1.05 & 0.94 & 0.2 \\
\hline $17: 1$ & 0 & 0 & 0 & 0 & 0.78 & 0.89 & 0 & 0.06 & 0 & 0 \\
\hline $17: 0$ & 1.01 & 0.62 & 0.99 & 1.15 & 0.96 & 1.72 & 1.09 & 1.26 & 1.12 & 0.63 \\
\hline $18: 2 \omega(8,14)$ & 1.85 & 0.29 & 0.83 & 1.3 & 0.52 & 0.63 & 0.31 & 0.5 & 0.36 & 0.06 \\
\hline $18: 2 \omega(7,14)$ & 0.81 & 0.09 & 0.52 & 0.45 & 0.31 & 0.17 & 0.22 & 0.14 & 0.04 & 0 \\
\hline $18: 1 \omega 9$ & 4.3 & 1.41 & 6.09 & 4.33 & 3.78 & 4.71 & 3.19 & 3.9 & 3.49 & 0.85 \\
\hline $18: 1 \omega 8^{b}$ & 1 & 0.39 & 1.16 & 1.11 & 1.63 & 0.05 & 0.01 & 0.02 & 0.02 & 0 \\
\hline $18: 1 \omega 7$ & 3.11 & 0.85 & 2.99 & 3.01 & 4.16 & 2.83 & 1.53 & 2.88 & 2.69 & 0.68 \\
\hline $18: 0$ & 26.63 & 71.86 & 36.97 & 40.2 & 26.76 & 32.39 & 57.15 & 43.09 & 54 & 77.6 \\
\hline 10Me18:0 & 1.06 & 0.28 & 0 & 0.67 & 0 & 0 & 0 & 0 & 0 & 0 \\
\hline $20: 1$ & 0 & 0 & 0 & 0 & 0 & 0.32 & 0.29 & 0.25 & 0 & 0 \\
\hline $20: 0$ & 0.72 & 0.39 & 0.72 & 0.67 & 0.7 & 0.91 & 0.68 & 0.6 & 0.66 & 0.37 \\
\hline $\mathrm{mol} \mathrm{l}^{-1} \times 10^{-10}$ & 213.7 & 684.5 & 166.1 & 197.6 & 357.1 & 1339 & 3162 & 159.4 & 187.2 & 604.59 \\
\hline
\end{tabular}




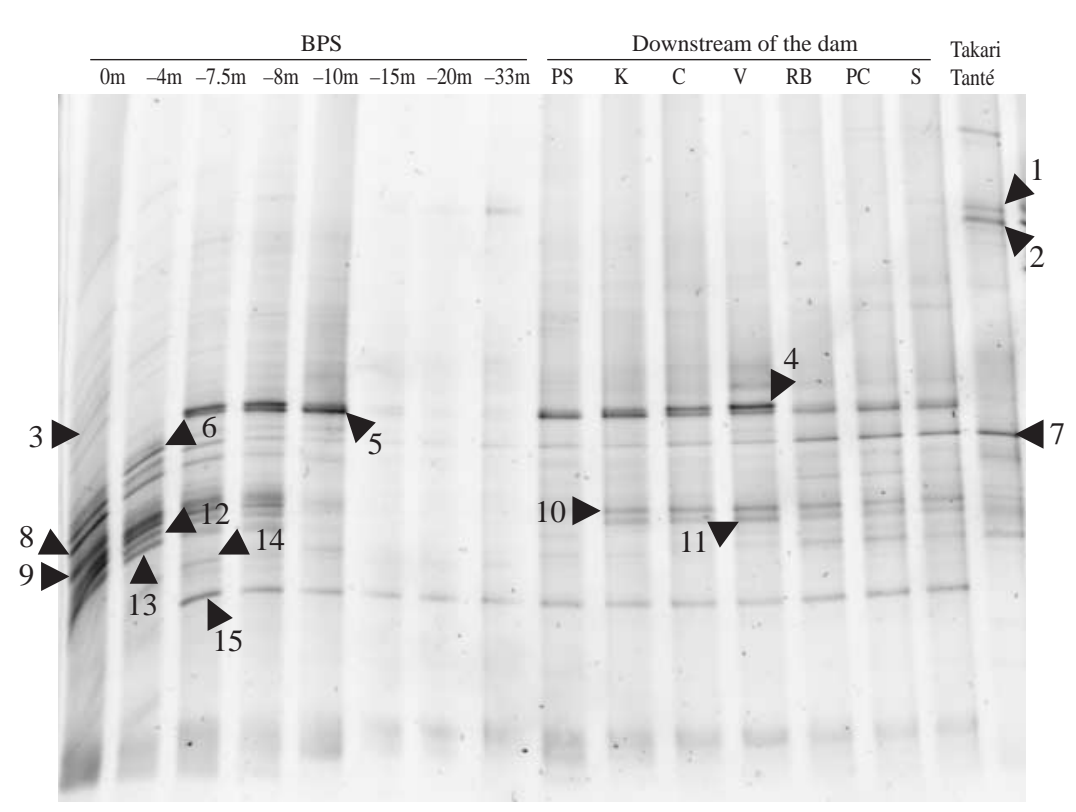

Fig. 5. Negative image of denaturing gradient gel electrophoresis (DGGE) gel containing polymerase chain reaction (PCR)-amplified fragments of bacterial 16S rRNA genes. Stations are designated as described in Fig. 1. Numbers 1 to 15 are PSBAC-1 to PSBAC-15

product was obtained from bottom samples $(15,20$, and $33 \mathrm{~m}$ ) and several PCR samples were pooled together in order to produce enough signal in the denaturing gel. Despite the fact that the band intensity was clearly lower than in other samples, it was possible to detect relative intensities for each band from the high resolution original image $(1312 \times 1034$ pixels, 12 bits dynamic range) that was used for the statistical analysis of the gel (see below). Four different bacterial fingerprints were observed in the vertical profile (Fig. 5). The first corresponded to the aerobic zone ( 0 and $4 \mathrm{~m})$ and showed 23 to 27 bands. The second corresponded to the oxycline ( 7.5 and $8 \mathrm{~m})$, where we detected 32 and 35 bands. Here, we observed a decrease in the relative intensity of most bands from the aerobic zone, while 2 bands (PSBAC-4 and PSBAC-5) became predominant ( $35 \%$ of total intensity at $7.5 \mathrm{~m}$ and $20 \%$ at $8 \mathrm{~m}$ ). The third pattern was observed below the oxycline level (10 m), where those 2 bands became dominant and represented $55 \%$ of total intensity. Finally, down to the bottom the fingerprints were quite similar, with one important band (PSBAC-15) representing around 20\% of total intensity. Downstream from the dam, in the Sinnamary River, the bacterial fingerprint from the first station (PS) was quite similar to the fingerprint from $10 \mathrm{~m}$ as expected because water which overflows into the river typically comes from this reservoir depth. Two bands remained dominant until the Vénus station, where a large tributary converged. After this critical point, 3 bands became dominant down to the harbor: PSBAC-5, PSBAC-7, and PSBAC-15. There were important differences in the DGGE patterns from the upstream station (Takari Tanté) and the downstream stations, which reflected changes in the bacterial assemblages due to the presence of the reservoir.

The comparative statistical analysis of the fingerprints from all the stations essentially confirms this pattern (Fig. 7). The most apparent feature in the dendrogram is that the upstream station (Takari Tanté) was separated from the rest. This is a consequence of the strong shift in the original bacterial assemblage caused by the dam. In addition, samples from the aerobic zone (surface and $4 \mathrm{~m}$ ) of the reservoir grouped closely and were different from the other samples. Samples from the oxic-anoxic interface $(7.5$ and $8 \mathrm{~m})$ were closely related, whereas those from the depth of maximal cell abundance $(10 \mathrm{~m})$ and from the Sinnamary River up to $11 \mathrm{~km}$ after the dam grouped together. Samples from the bottom of the reservoir $(15,20$, and $33 \mathrm{~m})$ grouped in the same branch. Samples from the last $30 \mathrm{~km}$ to the sea were divided into 2 groups: one including stations before Vénus and another grouping stations after Vénus. This dichotomy shows the influence of the tributary Crique Vénus on the bacterial assemblages of the Sinnamary River.

Archaeal fingerprints (Fig. 6), were obtained only from some reservoir samples in the anaerobic layer $(7.5,8,10$, and $15 \mathrm{~m})$ and from all the river stations downstream of the dam. No PCR product was obtained

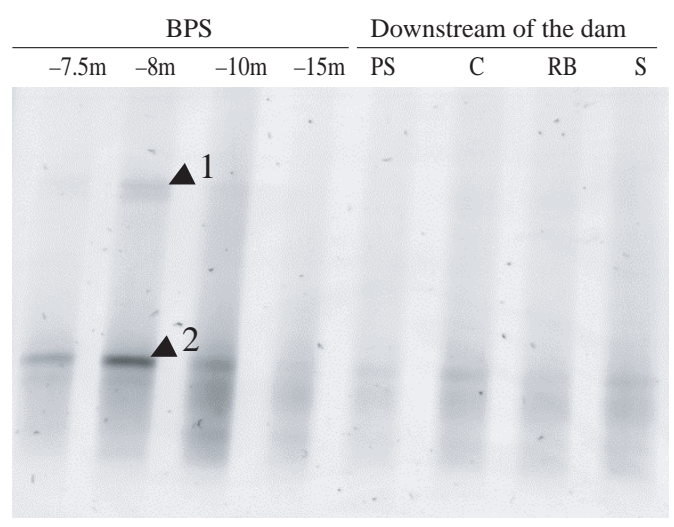

Fig. 6. Negative image of DGGE gel containing PCR-amplified fragments of archaeal 16S rRNA genes. Stations are designated as described in Fig. 1. Number 1 is PSARC-1. Number 2 is PSARC-2 


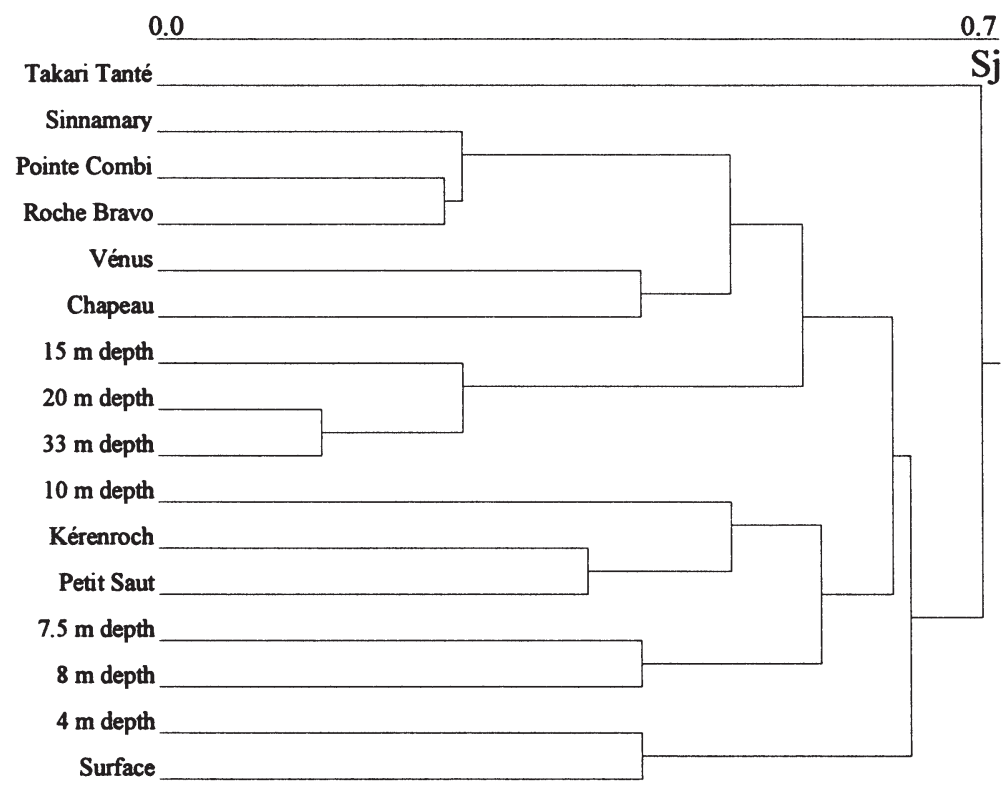

Fig. 7. Dendrogram representing the relations between the different samples, after unweighted pair group average linkage method (UPGMA) computation by Jaccard coefficient (Sj) of a binary matrix generated from the bacterial DGGE profiles. Bar indicates disimilarity values

from the aerobic layers or from the deepest part of the reservoir. The number of archaeal DGGE bands was lower than the number of bacterial bands, and only 3 bands were well defined in the fingerprint. These bands were excised from the gel but only 2 of them yielded sequences.

\section{Phylogenetic affiliations of predominant community members}

Seventeen bands from the DGGE fingerprints were excised, reamplified, purified, and successfully sequenced (15 for bacteria and 2 for archaea, see Figs 5 \& $6)$. The resulting parsimony tree where partial sequences were inserted is presented in Fig. 8. The 16S rDNA-defined populations were distributed throughout the tree, indicating that microbial genetic diversity was high in the system. Members of Proteobacteria $(\alpha, \beta$, and $\gamma$ subdivisions), green sulfur bacteria and Cytophaga-Flavobacterium-Bacteroides (CFB) phylum were predominant. Cyanobacteria were abundant in the surface layer. Archaeal sequences related to methanogens and thermoplasmales were also retrieved. Thus, between 60 and $85 \%$ of the total DGGE band intensity from the bacterial populations represented in the fingerprinting was identified for most of the stations. At the bottom layers (20 and $33 \mathrm{~m}$ ), however, only $45 \%$ of total band intensity could be identified. This failure was due to the difficulty of re-amplifying the faint bands obtained in these profiles because of the low PCR amplification yield obtained from the original samples.

Table 3 shows the physiology of the closest cultured microorganism for those 16S rDNA sequences that exhibited levels of similarity of $\geq 95 \%$ (genus level identity). All of the closest relatives had metabolism that were compatible with the environment from where the band was retrieved. On the basis of these data, 4 different metabolic groups were tentatively identified. First, the sequences PSBAC-14 and PSBAC-15 were related to 2 genera of methanotrophic bacteria, both type II methanotrophs: Methylocystis and Methylosinus (97 and $96 \%$ similarity, respectively). This confirmed results obtained by PLFA analysis. The methanotroph PSBAC-15 was detected in the oxic-anoxic interface and in the anaerobic part of the reservoir and all along the river down to the dam, but not upstream. The relative intensity of these 2 bands reached $18 \%$ of total intensity at the oxycline level. Second, 2 sequences belonging to photosynthetic sulfur bacteria were

Table 3. Ecophysiology of the closest relatives of the $16 \mathrm{~S}$ rDNA sequences that exhibited levels of similarity $\geq 95 \%$ (genus level identity)

\begin{tabular}{|lcccc|}
\hline Phylogenetic group & Sequence & Related sequence & Similarity (\%) & Ecophysiology \\
\hline$\beta$-Proteobacteria & PSBAC-11 & Denitrifying Fe-oxidizing bacteria & 97 & Denitrification and Fe oxidation \\
$\gamma$-Proteobacteria & PSBAC-12 & Stenotrophomonas maltophilia & 99 & Aerobe \\
$\alpha$-Proteobacteria & PSBAC-6 & Chromobacterium lividum & 98 & Fe oxidation \\
$\alpha$-Proteobacteria & PSBAC-9 & Erythromonas ursincola & 97 & Aerobe \\
$\alpha$-Proteobacteria & PSBAC-14 & Methylocystis sp. & 97 & Methanotroph \\
$\alpha$-Proteobacteria & PSBAC-15 & Methylosinus sporium & 96 & Methanotroph \\
Green sulfur bacteria & PSBAC-4 & Chlorobium limicola & 97 & Anoxygenic sulfur photosynthesis \\
Cytophaga & PSBAC-1 & Chryseobacterium balustinum & 95 & Facultative anaerobe \\
Cytophaga & PSBAC-2 & Chryseobacterium meningoseptic & 99 & Facultative anaerobe \\
Cytophaga & PSBAC-3 & Flavobacterium ferrugineum & 96 & Facultative anaerobe \\
\hline
\end{tabular}




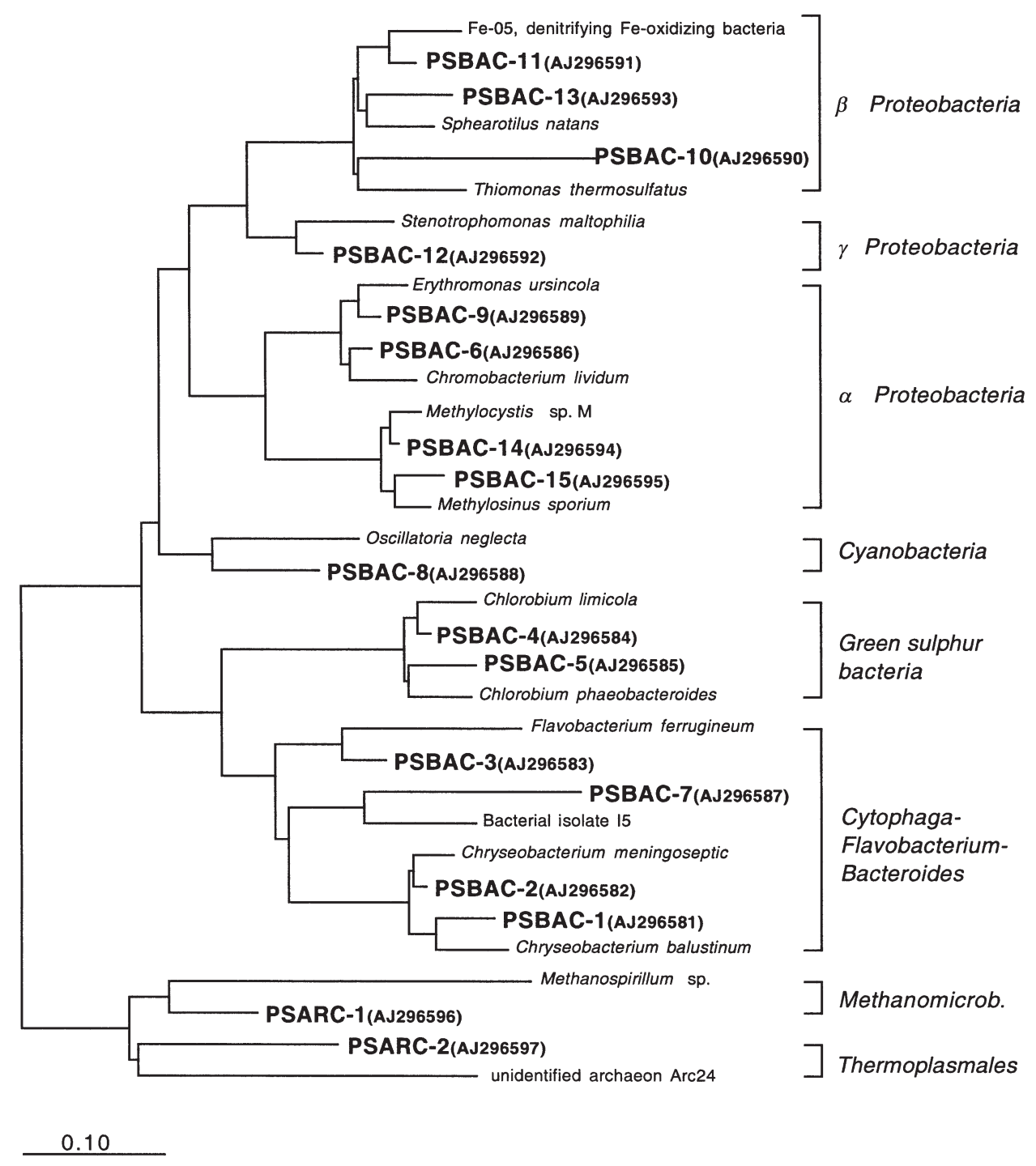

Fig. 8. Phylogenetic affiliation within the domains of Bacteria and Archaea of the excised bands obtained from the gels in Figs $5 \& 6$. The tree was constructed by adding by parsimony analysis the partial sequence data to a previously validated and optimized tree. Scale bar $=0.10$ mutations per nucleotide position obtained. One, PSBAC-4, showed $97 \%$ similarity to Chlorobium limicola and this agreed with HLPC data. The other, PSBAC-5, had only $92 \%$ similarity to $C$. phaeobacteroides. The relative intensity of these 2 DGGE bands reached $54 \%$ of total intensity below the oxycline, at $10 \mathrm{~m}$ depth. Third, sequences related to iron oxidizers were obtained. This can be expected on the basis of the high concentrations of iron measured in the reservoir (Fig. 2). These were PSBAC-6 (98\% similarity to Chromobacterium lividum) and PSBAC-11 (97\% similarity to a denitrifying iron-oxidizing $\beta$ Proteobacterium). An additional sequence, PSBAC-13, was also related to iron oxidizers $(92 \%$ similarity to Sphaerotilus natans). When grouped, iron-oxidizing bacteria were shown to contribute around $20 \%$ of total band intensity in the aerobic zone, around $10 \%$ at the interface and $5 \%$ at $10 \mathrm{~m}$. This is consistent with the hypothesis of an active iron metabolism in the reser- voir. The fourth metabolic group consisted of heterotrophic facultative anaerobes belonging to the $\mathrm{CFB}$ phylum. They were more abundant in the original incoming waters (more than $40 \%$ of the total intensity).

Sequences not included in Table 3 were more distantly related to cultured strains. However, they offered information about other physiological groups present in the system. Thus, oxygenic phototrophs were represented by PSBAC-8 (related in the database to the cyanobacterium Oscillatoria). Vaquer et al. (1997) determined by microscopy that Oscillatoria neglecta was the dominant cyanobacterium in Petit Saut reservoir. The relative intensity of PSBAC-8 represented $6 \%$ of the total intensity at the interface but only $1 \%$ in deeper layers. Downstream of the dam, this sequence represented $3 \%$ of the total bacterial band intensity. Methanogens are also expected to be a very important group. An archaeal sequence related to 
methanogens was recovered at the oxic-anoxic interface (PSARC-1), but the predominant archaeal sequence (PSARC-2) was related to the thermoplasmales and relatives group. Finally, other expected groups such as chemolithoautrophic sulfur bacteria might be represented by the sequence PSBAC-10, which had Thiomonas as the closest relative in the database.

\section{DISCUSSION}

The construction of Petit Saut dam induced a strong change on both the physico-chemical conditions and on the microbial assemblages inhabiting the Sinnamary River. Anaerobic microbial degradation of the submerged rain forest, favored by warm equatorial temperatures, resulted in the production of large amounts of dissolved organic matter and reduced compounds, such as methane and sulfide. Anaerobic conditions also induced transfer of ferrous compounds from the rain forest soil (laterite) to the water column. Downstream of the dam, aeration of deep waters favored the biological oxidation of those reduced compounds generated in the reservoir. Altogether, microbial activities ruled the dynamics of the whole system.

Several stratified populations were detected in the vertical profile at the BPS station, and it has been shown that their stratification and abundance are dependent on functional parameters of the hydroelectric plant (Dumestre et al. 1999b). Conditions generated by the dam favored microbial growth and biomass accumulation, and the peak of microbial abundance evolves cycles yearly with a maximum during the dry season (Dumestre et al. 1999b). Moreover, the value of maximal abundance $\left(D\right.$, in $10^{6}$ bacteria $\left.\mathrm{ml}^{-1}\right)$ is clearly influenced by the average outflow $\left(A O\right.$, in $\left.\mathrm{m}^{3} \mathrm{~s}^{-1}\right)$, according to the following equation: $D=32-0.05 \times A O$ $\left(\mathrm{r}^{2}=0.665, \mathrm{p}=0.025, \mathrm{n}=8\right)$. When $A O$ increases, residence time of water masses decreases and bacteria cannot reach their maximal abundance value. In addition, the depth of the oxycline $(z$, in $\mathrm{m})$ is influenced also by outflow according to $z=0.007 \times A O+4.06\left(\mathrm{r}^{2}=\right.$ 0.505, $\mathrm{p}=0.006, \mathrm{n}=11$ ).

It is well known that several bacterial genera can be detected by the use of specific PFLA markers such as those described in the genuses Desulfovibrio (Boon et al. 1977), Desulfobacter (Taylor \& Parkes 1983), Desulfobulbus (Vainshtein et al. 1992), Thiobacillus (Kerger et al. 1986), and Clostridium (Chan et al. 1971) and by methanotrophs (Bowman et al. 1991). In the present work we focused on methanotrophs and sulfate-reducing bacteria. Unfortunately, the genus Thiobacillus was not addressed by PLFA and we cannot add further data on the presence of chemolithoautrophic sulfur bacteria in the system.
We used the 18:1 108 fatty acid as biomarker for type II methanotrophs (Guckert et al. 1991). This type was detected throughout the aerobic part of the reservoir and in the Sinnamary River. However, the PFLA biomarker for type I methanotrophs (16:1 108 , for example) was not detected. We could not detect type I methanotrophs by DGGE either. This seems to be atypical since types I and II methanotrophs are generally associated in most ecosystems (Galchenko et al. 1988, Vecherskaya et al. 1993, Sundh et al. 1995). Vecherskaya et al. (1993) reported that type II methanotrophs were K-strategists, while type I were r-strategists. We do not have a clear explanation for the lack of type I methanotrophs in Petit Saut, but one explanation could be related to the maturation state of the reservoir. Methanotrophic activity was highly efficient in the reservoir 1 yr after the impounding, when the ecosystem had reached a certain equilibrium (Dumestre et al. 1999b). PLFA analyses were carried out at the end of 1996, 2 yr after the impounding, and thus methanotrophic communities adopting a K-strategy, that is, relative to organisms living in a climax environment (Odum 1969), might be expected.

In order to estimate the relative abundance of methanotrophs in Petit Saut reservoir, we compared specific PLFA concentrations versus total bacterial PLFA. For that, we took into consideration that 18:1 18 accounted for $57 \%$ of the whole methanotrophic PLFA composition. This value was determined in an enriched culture obtained from the oxycline of the same system (Dumestre et al. 1999a) and fitted well within the range from 19 to $68 \%$ reported in the literature (Bowman et al. 1991, Guckert et al. 1991). Using this same approach, Vecherskaya et al. (1993) found methanotrophs in different horizons from a tundra soil making up between 1 and $23 \%$ of total bacterial abundance. Whittenbury et al. (1976) had estimated this percentage to be $10 \%$ in lake ecosystems, while Galchenko et al. (1989) had shown that this contribution could reach $40 \%$ in hydrothermal marine ecosystems. In Petit Saut reservoir we found that the contribution of methanotrophic bacteria to the overall bacterial biomass in the aerobic water column ranged between 7 and $11 \%$. Methylosinus-related sequences obtained from the DGGE fingerprints had a relative abundance ranging between 3 and $24 \%$. Therefore, both approaches gave reasonable agreement. On the other hand, PLFA from methanotrophs were detected only in the oxic-anoxic interface and in the aerobic zone, whereas $16 \mathrm{~S}$ rDNA sequences corresponding to methanotrophs (PSBAC-14 and -15) were recovered throughout the reservoir (in the anaerobic zone their relative abundance was $15 \%$ on average). In this case, comparison between methods agrees but only in the zone where methanotrophic activity was expected to 
be higher. This suggests that methanotrophs are very active at the oxic-anoxic interface and that sequences found by PCR in the hypolimnion may correspond to inactive cells with degraded membranes. Finally, DGGE indicated that only a Methylosinus sporiumrelated sequence (PSBAC-15) was present in the Sinnamary River downstream of the dam, with a relative intensity ranging between 6 and $15 \%$ of total band intensity. Thus, such a population has to be responsible for the methane and oxygen consumption that takes place after the dam (Dumestre et al. 1999a).

To detect sulfate-reducing bacteria we used 10Me16:0 PLFA. These bacteria were found preferentially in a narrow layer just below the oxic-anoxic interface where green sulfur bacteria accumulated, despite the fact that sulfate was present all along the vertical profile. This indicates that they could be in close association with photosynthetic bacteria (both showed a peak in concentration at the same depth; see Fig. 4). A close association between sulfate reducers and Chlorobium has been shown in mixed cultures (Biebl \& Pfennig 1978). Thus, a loop between sulfide-producing and sulfide-consuming bacteria was established in the reservoir. Sulfate-reducing bacteria, however, were not detected as predominant groups by DGGE. This could indicate that they were a small but very active proportion of the microbial assemblage at these depths. Some of the minor bands that were not excised from the gel could correspond to sulfate reducers, or they could be under the detection limit of the staining solution. More information might be obtained from the weak bands by using Southern hybridization with sulfate reducer-specific probes (Muyzer et al. 1998) or by the use of specific DGGE primers (Teske et al. 1998). This could also be the case for purple photosynthetic bacteria that were detected by pigments but not by the DGGE fingerprinting. In fact, working with natural communities, DGGE does not detect populations whose abundance is less than 0.3 to $1 \%$ of the total cell count (Casamayor et al. 2000).

Photosynthetic sulfur-oxidizing bacteria (green sulfur bacteria) were detected by DGGE in both the anaerobic layers and in most stations after the dam. In the reservoir the intensity of DGGE bands belonging to Chlorobium sp. matched the distribution of bacteriochlorophyll. According to the picture obtained from DGGE, brown-pigmented C. phaeobacteroides predominated in the lower part of the photosynthetic layer (39\% intensity at $10 \mathrm{~m})$, whereas green-pigmented $C$. limicola predominated at the top part of such a layer (22\% intensity at 7 to $8 \mathrm{~m}$ ). The better adaptation of brown than green Chlorobium sp. to light limitation is a well-known fact which has been observed in several stratified systems (e.g. Parkin \& Brock 1980, Montesinos et al. 1983). Below $15 \mathrm{~m}$, less than $0.5 \%$ of incident irradiance was measured and very few photosynthetic cells were present. Downstream of the dam both populations were diluted out, except at the Vénus station, where the tributary seemed to increase the biomass of C. limicola.

Finally, methanogens were recovered by DGGE only from the oxic-anoxic interface. The presence of such populations below this interface was not well reflected in the DGGE gel. However, high dissolved methane concentrations were measured in the anaerobic layer, and the methane peak found at $10 \mathrm{~m}$ reflected in situ production. This could be explained by the fact that anaerobic ciliates were very abundant in the Petit Saut reservoir (Vaquer et al. 1997), and these organisms could carry endosymbiontic methanogens (Embley \& Finlay 1993). Such ciliates (and therefore endosymbiontic methanogens) might escape our sampling strategy.

The statistical analysis carried out on the bacterial DGGE gel (53 bands were used for the analysis) provides a realistic view of the whole system. Stations were grouped according to their geographic location and in agreement with the internal functioning of the dam and the physico-chemical characteristics of the water. This confirmed the suitability of this type of analysis to give a fast overview of the similarities and differences between the assemblages from different stations. Thus, the dendrogram showed that the aerobic bacterial assemblages from the reservoir (dominated by cyanobacteria and iron oxidizers) and from the original river waters (dominated by members of the CFB phylum) were different. The assemblage close to the oxic-anoxic interface (dominated by methanotrophs on the top and by green-pigmented green sulfur bacteria below) was also different from the assemblage living in strictly anaerobic depths a few meters below (dominated by brown-pigmented green sulfur bacteria). Downstream of the dam, bacterial populations were initially related to the sample taken at $10 \mathrm{~m}$, but along the river the CFB PSBAC-7 increased progressively, becoming an important member of the assemblage again (see Fig. 5). In the upstream community, specific sequences belonging to CFB (PSBAC3), iron-oxidizing bacteria (PSBAC-6), cyanobacteria (PSBAC-8), and methanotrophs (PSBAC-15) were detected. However, several of these populations did not develop massively in the reservoir despite the potentiality of their metabolisms. Instead, other populations that were not present in the river (or that were present but under the detection limit) developed massively in Petit Saut, especially those related to the oxidation of sulfide, iron, and methane (PSBAC-5, PSBAC-13, and PSBAC-14, respectively).

Petit Saut is a warm ecosystem not limited by organic matter because of the presence of the submerged 
forest. Because of the continuous bacterial input from tributaries, air, the rain forest, animals, and soils, the bacterial richness in this equatorial region must be much higher than we have shown in this work. For instance, more than 120 species of algae have been described in Petit Saut (Vaquer et al. 1997). For a more detailed cataloging of bacterial and archaeal diversity, more time-consuming molecular methods, such as PCR cloning, are required. Using a fingerprinting approach we have shown, however, how those microorganisms present in low abundance develop and actively participate in a new equilibrium. Just a few bacterial populations (15 major bands) were really favored by the new physico-chemical conditions in the reservoir, but the potential of the assemblage to respond to environmental changes is a clear example of the plasticity of microbial communities.

Acknowledgements. We thank sincerely all the staff of Petit Saut Laboratory for help, and technical and human support. We are also grateful to EDF/CNEH for financial support, and particularly to Chantal Sissakian. Parts of this work were also funded by project MIDAS (Microbial Diversity in Aquatic Systems, MAS3-CT97-0154) from the European Union. We also thank Professor Louis Labroue for starting this project and Mrs Yvette Durand for managing the administrative part of the project with virtuosity. The contribution of the anonymous reviewers is acknowledged.

\section{LITERATURE CITED}

Altschul SF, Gish W, Miller W, Myers EW, Lipman DJ (1990) Basic local alignment search tool. J Mol Biol 215:403-410

Amann RI, Ludwig W, Schleifer KH (1995) Phylogenetic identification and in situ detection of individual microbial cells without cultivation. Microbiol Rev 59:143-169

Biebl H, Pfennig N (1978) Growth yields of green sulfur bacteria in mixed cultures with sulfur and sulfate-reducing bacteria. Arch Microbiol 117:9-16

Boon JJ, De Leeuw JW, Van Der Hoek GJ, Vosjan JH (1977) Significance and taxonomy value of iso and anteiso monoenoic fatty acid and branched 13-hydroxy fatty acids in Desulfovibrio desulfuricans. J Bacteriol 129:1183-1191

Bowman JP, Skerratt JH, Nichols PD, Sly LI (1991) Phospholipid fatty acid and lipopolysaccharide fatty acid signature lipids in methane-utilizing bacteria. FEMS Microbiol Ecol 85:15-22

Casamayor EO, Schäfer H, Bañeras L, Pedrós-Alió C, Muyzer G (2000) Identification of and spatio-temporal differences between microbial assemblages from two neighboring sulfurous lakes: comparison by microscopy and denaturing gradient gel electrophoresis. Appl Environ Microbiol 66:499-508

Carbon Dioxide Information Center (CDIC) Numeric Data Collection (1986) Worldwide organic soil carbon and nitrogen data, NDP-O18. Oak Ridge National Laboratory, Oak Ridge

Chan M, Himes RH, Akagi JM (1971) Fatty acid composition of thermophilic, mesophilic and psychrophilic Clostridia. J Bacteriol 106:876-881

Cline JD (1969) Spectrophotometric determination of hydrogen sulfide in natural waters. Limnol Oceanogr 14:454-458
Dumestre JF, Guézennec J, Galy-Lacaux C, Delmas R, Richard S, Labroue L (1999a) Influence of light intensity on methanotrophic bacterial activity in Petit Saut reservoir, French Guiana. Appl Environ Microbiol 65:534-539

Dumestre JF, Vaquer A, Gosse P, Richard S, Labroue L (1999b) Bacterial ecology of a young equatorial hydroelectric reservoir (Petit Saut, French Guiana). Evidence of reduced compound exhaustion and bacterial community adaptation. Hydrobiologia 400:75-83

Embley TM, Finlay BJ (1993) Systematic and morphological diversity of endosymbiotic methanogens in anaerobic ciliates. Antonie van Leeuwenhoek 64:261-271

Galchenko VF, Abramochkina FN, Bezrukova LV, Sokolova EN, Ivanov MV (1988) The species structure of aerobic methanotrophic microflora in the Black Sea. Mikrobiologija 57:305-311

Galchenko VF, Ivanov MV, Lein AY (1989) Microbiological and biochemical process in oceanic water as indicators of submarine hydrotherm activity. Geokhimija 57:1075-1088

Galy-Lacaux C, Delmas R, Jambert C, Dumestre JF, Labroue L (1997) Gaseous emissions and oxygen consumption in hydroelectric dams: a case study in French Guyana. Global Biogeochem Cycles 11:471-483

Gosse P, Grégoire A (1997) Dispositif de réoxygénation artificielle du Sinnamary à l'aval du barrage de Petit Saut (Guyane). Hydroécol Appl 9:23-56

Guckert JB, Ringelberg DB, White DC, Hanson RS, Bratina BJ (1991) Membrane fatty acids as phenotypic markers in the polyphasic taxonomy of methylotrophs within the Proteobacteria. J Gen Microbiol 137:2631-2641

Guézennec J, Fiala-Medioni A (1996) Bacterial abundance and diversity in the Barbados Trench determined by phospholipid analysis. FEMS Microbiol Ecol 19:83-93

Harry M, Gambier B, Bourezgui Y, Garnier-Sillam E (1999) Evaluation of purification procedures for DNA extracted from organic rich samples: interference with humic substances. Analysis 27:439-442

Kerger BD, Nichols PD, Antworth CA, Sand W and 4 others (1986) Signature fatty acids in the polar lipids of acid producing thiobacilli: methoxy, cyclopropyl, a hydroxycyclopropyl and branched and normal monoenoic fatty acid. FEMS Microbiol Ecol 38:67-73

Kreader CA (1996) Relief of amplification inhibition in PCR with bovine serum albumin or T4 gene 32 protein. Appl Environ Microbiol 62:1102-1106

Le Bris S, Plante-Cuny MR, Vacelet E (1998) Characterisation of bacterial and algal pigments and breakdown products by HPLC in mixed freshwater planktonic populations. Arch Hydrobiol 143:409-434

Montesinos E, Guerrero R, Abellà C, Esteve I (1983) Ecology and physiology of the competition for light between Chlorobium limicola and Chlorobium phaeobacteroides in natural habitats. Appl Environ Microbiol 46:1007-1016

Muyzer G (1998) Structure, function and dynamics of microbial communities: the molecular biological approach. In: Carvalho GR (ed) Advances in molecular ecology. NATO Sciences Series. IOS Press, Amsterdam, p 87-117

Muyzer G, Brinkhoff T, Nübel U, Santegoeds C, Schäfer H, Wawer C (1998) Denaturing gradient gel electrophoresis (DGGE) in microbial ecology. In: Akkermans ADL, van Elsas JD, de Brijn FJ (eds) Molecular microbial ecology manual, Vol 3.4.4. Kluwer Academic Publishers, Dordrecht, p 1-27

Odum EP (1969) The strategy of ecosystem development. Science 164:262-270

Ouverney CC, Fuhrman JA (1999) Combined microautoradiography-16S rRNA probe technique for determination 
of radioisotope uptake by specific microbial cell types in situ. Appl Environ Microbiol 65:1746-1752

Parkin TB, Brock TD (1980) The effects of light quality on the growth of phototrophic bacteria in lakes. Arch Microbiol 125:19-27

Porter KG, Feig YS (1980) The use of DAPI for identifying and counting aquatic microflora. Limnol Oceanogr 25:943-948

Raskin L, Stromley JM, Rittmann BE, Stahl DA (1994) Groupspecific 16S rRNA hybridization probes to describe natural communities of methanogens. Appl Environ Microbiol 60: $1232-1240$

Richard S, Arnoux A, Cerdan P (1997) Evolution de la qualité physico-chimique des eaux de la retenue et du tronçon aval depuis la mise en eau du barrage de Petit Saut. Hydroécol Appl 9:57-83

Schauer M, Massana R, Pedrós-Alió C (2000) Spatial differences in bacterioplankton composition along the Catalan coast (NW Mediterranean) assessed by molecular fingerprinting. FEMS Microbiol Ecol 33:51-59

Stahl DA, Amann RI (1991) Development and application of nucleic acid probes. In: Stackebrandt E, Goodfellow M (eds) Nucleic acid techniques in bacterial systematics. Wiley, New York, p 25-248

Sundh I, Borga P, Nilsson M, Svensson BH (1995) Estimation of cell numbers of methanotrophic bacteria in boreal peatlands based on analysis of specific phospholipid fatty acids. FEMS Microbiol Ecol 18:103-112

Taylor A, Parkes RJ (1983) The cellular fatty acid of the sul-

Editorial responsibility: Karel Šimek,

České Budějovice, Czech Republic fate-reducing bacteria Desulfobacter sp., Desulfobulbus sp. and Desulfovibrio desulfuricans. J Gen Microbiol 129: 3303-3310

Teske A, Ramsing NB, Habicht $\mathrm{K}$, Fukui $\mathrm{M}$ and 3 others (1998) Sulfate-reducing bacteria and their activities in cyanobacterial mats of solar lake (Sinai, Egypt). Appl Environ Microbiol 64:2943-2951

Vainshtein M, Hippe H, Kroppenstedt RM (1992) Cellular fatty acid of Desulfovibrio species and its use in classification of sulfate-reducing bacteria. Syst Appl Microbiol 15: $554-556$

Vaquer A, Pons V, Lautier J (1997) Distribution spatio-temporelle du phytoplancton dans le réservoir de Petit Saut (Guyane Française). Hydroécol Appl 9:169-193

Vecherskaya MS, Galchenko VF, Sokolova EN, Samarkin VA (1993) Activity and species composition of aerobic methanotrophic communities in tundra soils. Curr Microbiol 27:181-184

White DC, Bibbie RJ, Herron JS, King JD, Morrison SJ (1979) Biochemical measurements of microbial mass and activity from environment samples. In: Costerton JW, Colwell RR (eds) Native aquatic bacteria: enumeration, activity and ecology. American Society for Testing and Materials, Philadelphia, p 69-81

Whittenbury R, Colby J, Dalton H (1976) Biology and ecology of methane oxidizers. In: Schlegel HG, Gottshalk G, Pfennig $N$ (eds) Symposium on microbial production and utilization of gases. E Goltze K.G, Göttingen, p 281-292

Submitted: April 21, 2001; Accepted: September 23, 2001 Proofs received from author(s): November 19, 2001 